\title{
The involvement of medical doctors in torture: the state of the art
}

\author{
Ole Vedel Rasmussen Copenhagen, Denmark
}

One of the first international meetings against doctors participating in torture took place in Copenhagen in 1986 (1), and the Statement of Madrid (2) was a very important outcome of this meeting. The second international meeting took place in Uruguay in December 1987 . We can all be very proud of what $\mathrm{Dr}$ Gregorio Martirena and the Uruguayan Medical Association has been able to do. The conclusions of that meeting in Uruguay are worthy of study, with a special emphasis on what has been done; then it will be up to us to discuss what we need to do in the future. At the Uruguay meeting, the so-called Montevideo Group was formed, consisting of the Uruguayan Medical Association, the Danish Medical Association, and the Rehabilitation and Research Centre for Torture Victims. This international committee (the Montevideo Group) was given the following objectives: (3)

1) The monitoring and investigation of violations by doctors of codes of medical ethics and human rights.

2) The establishment of tribunals to investigate and try cases where doctors violate human rights in countries where the local medical profession organisations cannot do so or where there is nobody legally responsible for professional discipline. Information about doctors who have participated in torture should be published to prevent them from practising medicine anywhere in the world.

3) To assist and protect doctors who come under threat because of their human rights activities.

4) To draw up a universal code of medical ethics which would refer to violations of human rights so that national medical associations and their members would have a clear policy. The code should serve as a guide for national legislation.

I would like to add another important task mentioned by Gregorio Martirena: that doctors all over the world should receive education in medical ethics.

We have now come together at the third international meeting concerning doctors and torture. I would like to describe what has been done, especially in Denmark since the last international meeting. The RCT has dedicated two newsletters $(4,5)$ to the topic, thus publishing information that was collected. In these newsletters we were able to publish news about the important work done by Gregorio Martirena and his colleagues in Uruguay; the work done by Veli Lök from Turkey; by Diana Kordon; and by Lucila Edelman and Dario Lagos from Argentina. Edelman and Lagos have published information about the participation in torture of ten doctors including their names: all ten remain at liberty, have not been punished, and are still allowed to practise medicine. Doctor Dadfar from Afghanistan has given out the names of five doctors. Dr Pross from Germany, Dr Mehdi from Pakistan and Dr Pagaduan-Lopez from The Philippines have also been able to tell us about doctors who participate in torture in their countries.

Another way of collecting information about doctors who participate in torture is to request it of those torture survivors with whom you are in contact in your treatment centres. I would like to suggest that we decide on a few questions to ask our clients to enable us to collect information about doctors/torturers. I would be very happy to assist in compiling all the data if it is sent to Denmark.

With great help from my colleagues and the RCT in January 1990 I published a book, a thesis, concerning the torture of 200 victims in 18 different countries (6). Forty-one persons said medical personnel had been involved in their torture. Fifteen persons stated they were examined prior to their torture. Nine said nontherapeutic administration of drugs was used against them, ten that a doctor was present during the torture, and 15 that they received medical resuscitation because they lost consciousness during torture.

The ways in which a doctor can participate or be involved in torture may be classified as follows:

1) to make a diagnosis,

2) to treat the patient,

3) the opposite of prophylactic work.

Examples of the third group include doctors' participation in: creating and inventing new sophisticated types of torture: punitive amputations; carrying out the death penalty, and in abuse of psychiatry.

High-risk doctors is a term we have used for those who work closely with the government forces 
responsible for torture. These might include military doctors, police doctors, or forensic doctors. It is important that we try to contact these doctors and tell them about their obligations concerning human rights. In their international congresses since the congress here in Bergen, Norway, 1981, the forensic doctors have included human rights sessions and Danish doctors have participated and given testimony and lectures about the consequences of torture, stressing the need for education of medical students. Since the Bergen Forensic Congress in 1981, other congresses have taken place in Oxford, Sri Lanka, Vancouver, Peking, and Havana.

In Denmark, we have initiated formal education in medical ethics which is included in the curriculum for medical students. We have observed that forensic doctors in other countries are also in charge of this sort of education. I believe this is of great importance because it is not only the students who receive education on medical ethics, but also the teachers - the forensic doctors who are working closely with the police.

In Denmark, we have examined the role of the doctor when assisting in police investigations (7). The medical role in these cases is very different from the doctor's normal relationship with his patient. Normally, when a doctor examines a patient, it is to relieve pain and suffering and to order relevant treatment. A police doctor's examination of an accused person can have serious consequences for the accused. In such cases, normal medical confidentiality no longer exists. Our analysis concludes that it would be a disaster to have special medical ethical rules for police, prison, or military doctors. Medical ethical rules should be universal, with no exceptions, and no medical examination should take place against a person's will.

The Danish Medical Association has just adopted a revised version of its medical ethical regulations. These rules clearly state that no doctors may participate in torture or inhuman or degrading treatment; there is an emphasis on the importance of the Tokyo Declaration. The only case we have had in Denmark concerning violation of the Tokyo Declaration has been in the context of forced feeding. However, Danish doctors work in Third World countries, and we have examples that they have violated the Declaration in Africa, for example, by issuing certificates that persons were fit for flogging. As a consequence, instruction in medical ethical obligations is stipulated in the contracts of doctors going to work in Third World countries.

Doctors working against torture are themselves at risk of becoming torture victims. We discussed this at a seminar in London concerning the treatment of torture survivors. On that occasion, a declaration was adopted and sent to several international organisations and published in medical journals (8). We have also been involved in concrete actions, for example in The Philippines and Uruguay.

At the start of our medical work against torture in the mid-1970s, we were very much involved in the documentation of torture (6). Today, the focus has shifted to involvement in treatment and rehabilitation. However, I believe, that we are now entering another new area where we will be used as doctors on factfinding missions to examine persons who have been tortured. Bent Sørensen can tell us more about the possibilities that exist for this through the United Nations and the European Human Rights Commission. In recent years, Danish doctors have participated as members of fact-finding missions to Venezuela, Turkey, and Nepal. We have just published an article about fact-finding missions in the Danish Medical Bulletin (9).

The United Nations adopted the Declaration on Medical Ethics in 1982. In 1992, ten years later, the Danish Government hopes to become a member of the UN Commission on Human Rights. In co-operation with the Danish Medical Association we are working on a declaration against doctors' participation in torture to be adopted by the United Nations.

We have co-operated with Penumbra Films and the $\mathrm{BBC}$ to produce a documentary film on doctors' participation in torture (10). I have just returned from a visit to Argentina and Chile where a great problem exists concerning the impunity of all the persons accused of having participated in torture under the military government. Hopefully, we as doctors can bring our colleagues who have participated in torture to justice and in this way avoid the medical profession being exempt from punishment.

During our stay in Chile we visited a colleague, $\mathrm{Dr}$ Pedro Marín, who is in jail there. Dr Marín went into exile in 1973, when Pinochet came into power. He returned and was arrested in January 1987 and heavily tortured, accused of having given medical help to persons involved in actions against Pinochet. We were able to visit him in the prison in Santiago only five days ago. He has not been released with all the other political prisoners because he is accused of terrorist acts. I have a letter, in which he asks for economic support to purchase books for his continuing medical education. I would like to propose that the participants of this meeting add their signatures to a letter we have written to support this colleague. I would also welcome any financial contributions to help him buy the books he needs. An RCT representative is going to Chile and will give him the letter and the money.

On our last day in Chile a great demonstration was arranged in Santiago to draw attention to the 90,000 disappearances of persons who have been imprisoned in Latin America. It was very impressive to be able to participate in the demonstration, and I would like to end this presentation with an account of one of the things we were shouting during the march:

'Quieremos la vida, quieremos la allegría, por eso luchamos sin descanso cada dia.'

'We want life, we want happiness. Together we fight day and night.' 
I think this is a fitting chant for the spirit of our meeting also.

\section{Acknowledgement}

I would like to thank the steering committee for inviting me to participate in this seminar and to congratulate it for being able to assemble so many people from all over the world. It is impressive to be together with so many doctors who are fighting under very difficult conditions for human rights.

Ole Vedel Rasmussen, $M D, D M S c$, is Consultant at the Rehabilitation and Research Centre for Torture Victims $(R C T)$ in Copenhagen, Denmark.

\section{References}

(1) Danish Medical Association and Rehabilitation and Research Centre for Torture Victims. Doctors, ethics and torture. Danish medical bulletin 1987; 34: 185-216.
(2) Statement of Madrid, Recommendations concerning doctors, ethics, and torture. Madrid, November 1989. International newsletter on treatment and rehabilitation of torture victims $1990 ; 2: 1$.

(3) Rasmussen O V, Espersen O, Pagaduan-Lopez J and Udsen P. Physicians in the face of ethics and torture. Lancet 1988; i: 112.

(4) International newsletter on treatment and rehabilitation of torture victims $1989 ; 1: 4$.

(5) International newsletter on treatment and rehabilitation of torture victims $1990 ; 2: 1$.

(6) Rasmussen O V. Medical aspects of torture. Danish medical bulletin 1990; 37 (suppl 1): 1-88 (thesis).

(7) Carle P, Jacobsen P, Kelstrup J, Helweg-Larsen K, Rasmussen O V, Rehof L A, Thomsen J L. Lægers medvirken ved politiets efterforskning. Furisten 1988; 7 : 294-312.

(8) Rasmussen O V. Doctors who treat torture victims. Lancet 1988; ii: 1265.

(9) Rasmussen O V, Helweg-Larsen K, Kelstrup J, Carle P, Rehof L A. The medical component in fact-finding missions. Danish medical bulletin 1990; 37: 371-374.

(10) Wearne P. Blood on their hands. Telegraph weekend magazine 1990 Sept 8: 24-30. 